\title{
COMPARATIVE ANALYSIS OF V2V AND A2A
} TECHNOLOGIES

\section{ANALIZA PORÓWNAWCZA TECHNOLOGII V2V ORAZ A2A}

\section{Agata Kołodziejska, Karolina Krzykowska, Mirosław Siergiejczyk}

Warsaw University of Technology. Faculty of Transport

Politechnika Warszawska. Wydział Transportu

\begin{abstract}
In recent years, around the world, there has been work underway on systems, which will increase not only the comfort of traveling but, above all, the safety and reliability of the road traffic. The systems in this field, designed to replace human beings in the future, thus eliminating their mistakes on the road, already have their prototypes. However, these prototypes are still being improved and require a lot of work so they could operate fully and reliably. The subject of the publication is a compilation of two new concepts in the field of Intelligent Transport Systems. These concepts are V2V (Vehicle - to - Vehicle) and A2A (Autonomous vehicle - to - Autonomous vehicle). Their comparison was carried out in terms of functionality, communication, vehicle equipment, legal aspects and the anticipated date of their entry into the market. Also examples of first tests and implementations of vehicles with driver assistance systems, and semi-autonomous vehicles were presented.
\end{abstract}

Keywords: ITS, V2V, A2A, autonomous vehicles

Streszczenie: $W$ ostatnich latach na calym świecie trwaja prace nad systemami, które zwiększa nie tylko komfort podróżowania, ale przede wszystkim zwiększa jego bezpieczeństwo oraz niezawodność ruchu drogowego. Systemy z tego zakresu, majace w przyszłości zastapić człowieka, a tym samym wyeliminować jego błędy na drodze, maja już swoje prototypy. Niemniej jednak prototypy te sa wciaż ulepszane oraz wymagaja jeszcze sporego naktadu pracy, aby mogły dziatać w petni samodzielnie oraz niezawodnie. Tematem publikacji jest zestawienie dwóch nowych koncepcji z zakresu Inteligentnych Systemów Transportowych. Koncepcje te to V2V (Vehicle - to - Vehicle) oraz A2A (Autonomous vehicle - to - Autonomous vehicle). Ich porównanie przeprowadzone zostało pod katem funkcjonalności, sposobu komunikacji, wyposażenia pojazdów, aspektów prawnych, a także przewidywanej daty ich wejścia na rynek. Przedstawione zostały również przykłady pierwszych testów $i$ wdrożeń pojazdów z systemami wspomagajacymi kierowce oraz pojazdów częściowo autonomicznych.

Stowa kluczowe: ITS, V2V, A2A, pojazdy autonomiczne 


\section{COMPARATIVE ANALYSIS OF V2V AND A2A TECHNOLOGIES}

\section{Introduction}

Mistakes made by road users such as drivers, cyclists and pedestrians are the main cause of most accidents. It was confirmed by in-depth studies conducted in the United States and the United Kingdom in the 1970s. ${ }^{1}$ In order to improve road safety, car manufacturers around the world are working on the introduction of advanced driver assistance systems. Some of these systems already function and they are available in certain car models. They allow to avoid dangerous traffic situations (collisions and accidents), which people cannot influence, for example, due to a limited field of view. However, a stage of the motorisation development, at which the human factor will be completely eliminated, will include putting of autonomous vehicles, which do not require the presence of a driver, into operation. In the pursuit of reaching this stage, the car manufacturers encounter a number of obstacles, ranging from the machine defect, and the way of data transmission, to the legal aspects. Undoubtedly, years of work and tests are needed for reliable operation of this type of technology. In order to see the stage, at which new technologies in the field of intelligent transport are, two of them will be juxtaposed, namely V2V (Vehicle - to - Vehicle) and A2A (Autonomous vehicle - to Autonomous vehicle).

\section{Comparative analysis}

\section{Functionality}

Vehicle-to-vehicle (V2V) is a car technology, which was designed in such a way, so as to create a wireless "ad hoc" network on roads. Owing to this fact, this technology can provide mutual communication of individual vehicles. The special equipment of these vehicles provides them with information about the situation on the road network around them. Therefore, it significantly extends the driver's room for manoeuvre, in comparison to his/her current knowledge of what happens directly in front of and behind the vehicle.

The cars covered by V2V technology have a driver warning system. It consists in receiving information from other vehicles, and then, warning the driver about the occurred danger by visual and/or audible alarming. An example may be a warning to the driver about obstacles or about a stopped vehicle on the lane so that he/she can safely bypass this safety-threatening object. The warning is carried out by displaying the appropriate symbol on the display in the car.

${ }^{1}$ Gaca S., Suchorzewski W., Tracz M.: Road traffic engineering. Theory and practice. [Inżynieria ruchu drogowego. Teoria i praktyka] Transport and Communication Publishers, Warsaw 2008, 2014 
Safety warning applications that are part of V2V technology primarily include:

- collision warning (FCW),

- emergency braking warning (EEBL),

- Left Turn Assist (LTA),

- Do Not Pass Warning (DNPW),

- Blind Spot/Lane Change Warning (BS/LCW),

- Parking Assistance (PA),

- Intersection Movement Assist (IMA).

The communication between vehicles significantly facilitates driving and increases the road safety. However, it is not able to replace the driver or make a decision for him/her.

However, Autonomous vehicle - to - autonomous vehicle (A2A) is a car technology, which consists in information transmission from a given autonomous vehicle to other autonomous vehicles. These vehicles are intended to be selfdriving and not requiring the presence of a driver. Owing to the communication with other vehicles, but also with transport infrastructure, they will be able to move on roads without any collisions. However, before that, semi-autonomous vehicles will be a safer form. In practice, it means that the vehicle is able to autonomously move and make decisions on the road with the use of artificial intelligence, it is completely automated, however, it requires the presence of a driver and taking control by him/her in case of detection of irregularities in operation.

A2A operation involves the autonomous vehicle communication in order to collect all data necessary for the proper vehicle self-driving. The priority is to avoid any collisions on the road, but also to relieve the driver by mechanisation of each of the driving stages.

In addition to the safety increase, it also results in the travel comfort increase. In contrast to $\mathrm{V} 2 \mathrm{~V}, \mathrm{~A} 2 \mathrm{~A}$ technology is able to replace the driver and make decisions on the road for him/her.

\section{Communication method}

V2V communication is carried out on the basis of the use of a wireless protocol similar to WiFi. It is called DSRC (Dedicated Short Range Communication). The microwave DSRC technology constitutes dedicated short-range communication. In combination with GPS technology, it results in a low-cost V2V communication system that provides a $360^{\circ}$ view of similarly equipped vehicles within the communication range of a given vehicle. Wireless networks on roads are also referred to as VANET networks. These networks will use a part of the $5.9 \mathrm{GHz}$ band, designated by the United States Congress, an unlicensed frequency also used by WiFi. The US V2V standard, commonly known as WAVE ("Wireless Access for Vehicular Environments") is based on the lower-level IEEE 802.11p standard already in 2004. 
The transmitted data, common to all vehicles, include:

- current GPS position,

- driving direction and acceleration of the vehicle,

- information on the vehicle control (gearbox condition, brake condition, angle of lock of the steering),

- vehicle path history and anticipated paths.

However, V2V does not include navigation, the Internet access, driver assistance systems, backup cameras and other advanced technologies.

In turn, $\mathbf{A 2 A}$ is to use $5 \mathrm{G}$ radio communication of a lower frequency. However, lower frequency provides coverage of a larger area by radio waves, and overcoming physical obstacles is then easier. Owing to the use of 5G technology, the vehicles will be able to receive large amounts of data from external servers. Then, there would be no need to analyse these data locally. According to the Intel company, each autonomous vehicle will generate an average of 4,000 GB every day. Therefore, it is necessary to provide a safe and reliable way of data transmission. Nevertheless, at the moment, there is no way to provide this type of communication on a mass scale, while $4 \mathrm{G}$ communication is not sufficient in this case. However, in February 2017, Intel proposed its original 5G communication platform (allowing to obtain the transmission speed of up to $7 \mathrm{Gbit} / \mathrm{s}$ ), intended for the autonomous transport segment. Owing to this platform, the car manufacturers as well as telecommunications operators can test prototypes of their solutions.

\section{Vehicle equipment}

The exact equipment of vehicles covered by $\mathrm{V} 2 \mathrm{~V}$ or A2A technology is not known, and it is mainly due to continuous work on them, as well as the constantly emerging improvements and changes. The number of the used devices will probably vary depending on a given brand and model of the car.

The basic equipment of vehicles with $\mathbf{V} \mathbf{2} \mathbf{V}$ technology will most likely require:

- ultrasonic sensors,

- laser distance sensors,

- radar sensors,

- cameras,

- general purpose processor and its related memory,

- radio transmitter and a transceiver,

- DSRC and GPS antennas,

- GPS receiver.

The equipment of autonomous vehicles with A2A technology will cover all devices in the vehicle with $\mathrm{V} 2 \mathrm{~V}$ technology, including 5G communication and GPS navigation. However, a significant difference in the equipment is the mandatory presence of a black box on board. This box will record the necessary driving parameters, and in case of semi-autonomous vehicles, it will be used to determine whether the driver took over the control at a given moment. 


\section{Legal aspects}

Almost all member states of the European Union (except for Spain and the United Kingdom) have signed and ratified the Convention on Road Traffic, also known as the Vienna Convention. It is a multilateral international treaty of the United Nations regarding general traffic regulations. Until 23 March 2016, all legal acts adopted by the Convention signatories had to require drivers to constantly control a moving vehicle.

Owing to the informational and warning role of $\mathbf{V 2 V}$ technology in road traffic, it complies with the provisions of the Vienna Convention. There are also no significant legal contraindications for the widespread use of this technology. However, when it comes to legal liability in the event of a collision or an accident, the driver bears it, because the system is only his/her auxiliary tool. The driver drives the vehicle and controls it. The driver cannot solely rely on its warnings, and he/she decides about manoeuvres on the road on his/her own.

In turn, regarding the vehicles covered by A2A technology, in 2016, a new paragraph under the name of "5bis" was added to Article 8 of the Vienna Convention.

As a result, automatic vehicles will comply with the Convention after the introduction of this amendment. However, the condition is the fact that the autonomous system will have to have the abilities to take over the control by the driver or it will meet the future requirements of ECE regulations. Further proposals for amendments to the convention were presented by Sweden and Belgium. They are still waiting for a decision.

In May 2017, Germany adopted regulations allowing self-driving vehicles to travel on public roads. However, the country of such concerns as BMW, Volkswagen and Daimler, imposed some restrictions to ensure that the autonomous vehicle tests will be safe.

The United States has dealt with the issue of legalising autonomous cars as early as in June 2011. The Nevada legislator has passed a law permitting the use of autonomous cars. Thus, Nevada has become the first jurisdiction in the world, where autonomous vehicles can be legally operated on public roads.

As far as federal traffic regulations are concerned, National Highway and Transportation Safety Administration (NHTSA) issued the updated guidelines for the safe development of autonomous vehicles in September 2016. The policy update consists of four parts: vehicle performance guidelines, state policy model, NHTSA up-to-date regulatory tools and possible new regulatory action that NHTSA considered to be helpful in the provision of the safe implementation of AV (Autonomous Vehicle) systems.

In the event of a collision or an accident involving the autonomous vehicle, the black box on its board is checked. If its recorded information shows that the driver has not interfered with the driving course, the vehicle manufacturer will be legally liable. 
Comparative analysis of $V 2 \mathrm{~V}$ and $A 2 A$ technologies

Analiza porównawcza technologii V2V oraz A2A

However, if it occurs that the driver took over the control of the vehicle, he/she will be liable. Then, it should be remembered then that manual control of the autonomous vehicle will involve a risk.

\section{Expected time of the technology entry into the market}

In January 2017, the National Highway and Transportation Safety Administration (NHTSA) published the proposed rule requiring each new vehicle to have Vehicleto-vehicle (V2V) communication capabilities. It is not an official requirement yet, however, if it comes into force in 2019 (probable date for such rules):

- the manufacturers would be able to gradually introduce this technology into their fleet for the next few years - after two years of modelling and after the adoption of the final rule, the introduction period would begin in 2021,

- successively, there would be a three-year initial period/introduction period in order to adapt the production cycle of the vehicle manufacturers, and all new vehicles subject to the final rule would communicate with each other already in 2023.

In the first place, NHTSA used a "breakeven" analysis in order to determine the calendar year, in which the cumulative economic value of safety-related benefits, owing to V2V communication, firstly exceeds the total costs for the vehicle manufacturers and buyers, in order to provide V2V capabilities. The analysis of alignment showed that this important threshold will be reached between 2029 and 2032, depending on the effectiveness of the application technology.

Then, NHTSA predicted an increase in the future benefits and costs of the proposed rule in subsequent model years after its entry into force. In this analysis, the first model year was identified, in which the safety benefits resulting from the requirement to equip the vehicles with $\mathrm{V} 2 \mathrm{~V}$ communication for their entire service life in the fleet will outweigh the higher initial costs of their manufacture. It showed that this would happen in 2024-2026, if the proposed rule would become effective in the model year of 2021. It would happen faster than a year of "breakeven" because focusing only on costs and benefits over the individual model years makes it possible to avoid the installation costs of $\mathrm{V} 2 \mathrm{~V}$ communication in vehicles manufactured in the previous model years.

It is expected that $\mathrm{V} 2 \mathrm{~V}$ systems will be installed in an increasing part of the vehicle fleet, as the manufacturers strive for meeting the proposed rule, which would require the installation in $100 \%$ of new vehicles by 2023 , which is over 16 million pieces a year. This high-volume production provides the manufacturers with the opportunity to reduce the system costs through the learning process. In 2023, 100 $\%$ of vehicles should be equipped with DSRC radiators.

However, as far as A2A technology is concerned, among The Guardian reports, there was information that by the end of the present decade, 200 million vehicles actively exchanging information with the global network (IoV/Internet of Vehicles) will appear on the streets all over the world. 
In Europe, the cities in Belgium, France, Italy and the United Kingdom plan to operate transport systems for cars without a driver, while Germany, the Netherlands and Spain allowed to test self-driving cars in traffic. The Swedish car manufacturer, Volvo, started testing of its 100 autonomous cars on public roads operated in regular traffic by regular customers until 2017. The company announced the cooperation with Swedish legislators and transport authorities in order to test cars on a 30-mile section of the road around Gothenburg until 2017, appointing Volvo as the first public pilot of fully autonomous vehicles. Analysts predict that the fully autonomous cars will be on sale by 2025-2030.

In Europe, the self-driving cars firstly must be tested in European conditions, and software should be adapted to more difficult conditions than the Californian ones. The European companies will work on it (the first tests on the European roads have been already conducted by Nissan, and Ford has also announced them), however, they are not so advanced in the work on the autonomous driving technology, as, e.g. Google or Tesla - they plan to show the first cars with such technology in 2020/2021.

The manager of the research and development centre of the Hitachi Europe technology company - Massimiliano Lenardi believes that such cars will not be on sale before 2025. In Europe, the first fully self-driving vehicles will most likely be trucks driving on motorways connecting large cities. They may appear even before 2025. According to his opinion, highly automated vehicles, but not fully autonomous, will appear earlier, even in 2020.

Freeing the Road: Shaping the future for autonomous vehicles (Uwolnić drogi: kształtowanie przyszłości pojazdów autonomicznych) is an independent report prepared by the think tank Policy Network to the order of Nissan Europe. A new independent economic analysis shows that the autonomous vehicles will start to generate additional $0.15 \%$ of the annual economic growth in Europe in the coming decades. As a result, the gross domestic product in the European Union (EU-28) countries will, in cumulative terms, be 5.3\% higher in 2050 than currently, and by that time, the autonomous vehicles will have generated GDP growth by a total of EUR 17 bn. ${ }^{2}$

During the international conference "Autonomous future of road transport" ["Autonomiczna przyszłość transportu drogowego"], organised by the Motor Transport Institute, the autonomous vehicles - for the first time on the Vistula River - were presented and the preliminary date of their admission to the use on the Polish roads was determined. By overcoming the existing barriers, including those related, e.g. to the Vienna Convention on road traffic, or the national Law on road traffic, it is possible to expect the marketing of autonomous vehicles of the 4th generation in 2025, while their share in the world scale will not exceed 1 percent of all vehicles, but a decade later, it will reach the value of tens of millions of pieces.

\footnotetext{
${ }^{2}$ Article: The autonomous vehicles are expected to generate EUR 17 billion for the European economy by 2050. [3]
} 
Comparative analysis of $V 2 \mathrm{~V}$ and $A 2 A$ technologies

Analiza porównawcza technologii V2V oraz A2A

\section{Examples of the first tests and implementation}

Recently, Volkswagen announced that it wants to introduce the communication technology between V2V vehicles since 2019, while Toyota already offers it in Japan. As the world's first manufacturer, almost two years ago, Toyota entered an active safety system package, ITS Connect, based on communication between cars and between vehicles and road infrastructure, into that market. It has already been found in the equipment of three Toyota models (among them, Pruis and Crown), offered on the Japanese market. ITS Connect is to be gradually introduced to subsequent Toyota models, helping to reduce the number of accidents at intersections.

In 2016, Mercedes announced that the E class will be its first series model, equipped with fully integrated communication between cars. The Mercedes system is already active in connection with the Comand Online information system, and it is available on 20 European markets, as well as in the United States and China.

However, Volvo started the car communication with the leading model line in Europe before the end of 2016, joining Mercedes-Benz and Toyota. At the beginning of October 2016, the Swedish car manufacturer published detailed information on its cloud-based solution during the introduction of new V90 Cross Country, which just one of the models that offer this technology (all vehicles of the 90 - S90, V90 and XC90 series).

With respect to the autonomous vehicle technology, at the end of 2010, the Google company revealed that it recorded almost 150,000 miles while testing its original, self-driving Toyota Prius. In August 2012, the Waymo team (the Alphabet's subsidiary) announced covering over 300,000 autonomous miles without accidents. In December 2013, four states (Nevada, Florida, California, and Michigan) adopted the laws on autonomous motor vehicles. In June 2015, the team revealed that they had travelled over 1,000,000 miles by autonomous vehicles. The prototype vehicle tests were carried out in Mountain View, in California. Already in the autumn of 2017, Waymo intends to admit self-driving taxis without a driver on the roads (city of Phoenix, Arizona). The autonomous taxis will include Chrysler Pacifica minivans of the Chrysler company, which Waymo has recently started the cooperation with.

The first car on the market, which had semi-autonomous driving technology was Mercedes-Benz S-Class in 2012. Mercedes-Benz took the opportunity to launch a redesigned S-class flagship model in order to show its autonomous car technology. In order to prove that it is ready for the real world, Mercedes revealed that S500 2014 travelled from Mannheim to Pforzheim in Germany, at the distance of more than 60 miles, on public roads through cities and on motorways.

In 2013, the Nissan company not only launch a self-driving Leaf EV model in Japan, which will be used for testing the autonomous technology, but also the car manufacturer promised that it will launch a number of self-driving vehicles. Already in March 2017, Nissan, as the only car manufacturer, decided to present the driving in the real urban traffic in London.

Ford tested its autonomous cars on the US roads, and now on the European roads. Ford intends to own an autonomous car for commercial use by 2021. In 2017, Ford starts testing its autonomous vehicles on motorways in Europe. 


\section{Conclusion}

This article raises the issue of the development of new technologies in the field of intelligent transport. Two concepts, namely V2V (Vehicle-to-Vehicle) and A2A (Autonomous vehicle-to-Autonomous vehicle), were presented. Their comparison in the same categories provides the reader with a certain view of their operation and advancement in implementation.

The carried-out analysis clearly shows that each new vehicle will have Vehicle-toVehicle communication capabilities around 2021-2023. On the other hand, it is expected that the sale of fully autonomous vehicles will start on a mass scale in 2025-2030. It means that V2V technology will enter the global market a bit faster than A2A. It results from the fact that for the purpose of communication between the autonomous vehicles, 5G technology operation is necessary, but it has not occurred yet. In addition, the autonomous vehicle technology is much more complicated than V2V technology. While the physical equipment of both types of vehicles is similar, the software solutions will vary from each other.

The confirmation of the approaching entry into everyday service of the discussed technologies are numerous tests carried out by car brands all over the world. The first prototypes of vehicles already exist, but they require some improvements and tests in more difficult weather conditions before their complete launch.

The publication has been prepared within the framework of the project Development of Road Innovations funded by the National Centre for Research and Development and the General Directorate for National Roads and Motorways (Contract No. DZP/RID-I-41/7/NCBR/2016).

\section{References}

[1] Article: All new cars could have V2V tech by 2023. Available: https://techcrunch.com/2017/02/02/all-new-cars-could-have-v2v-tech-by2023/ [Access: September 2017]

[2] Article: How it works: autonomous cars [Jak to działa: autonomiczne auta]. Available: https://www.chip.pl/2017/09/dziala-autonomiczne-auta/ [Access: November 2017]

[3] Article: The autonomous vehicles are expected to generate EUR 17 billion for the European economy by 2050 [Pojazdy autonomiczne mają przynieść europejskiej gospodarce 17 bilionów EUR do 2050 roku]. Available: https://newsroom.nissan-europe.com/pl/pl-pl/media/pressreleases/426164268 /pojazdy-autonomiczne-maja-przyniesc-europejskiej-gospodarce-17-bilionoweur-do-2050-roku [Access: November 2017]

[4] Article: Self-driving cars will not appear on the streets of Europe for a long time [Samojeżdżące auta jeszcze długo nie pojawią się na ulicach Europy]. Available: https://businessinsider.com.pl/motoryzacja/autonomicznesamochody-kiedy-w-europie/jt2lxqq [Access: November 2017]

[5] Article: Fully autonomous vehicles in Poland. Since when? [W pełni autonomiczne pojazdy w Polsce. Od kiedy?] Available: http://www.motofakty.pl/artykul/w-pelni-autonomiczne-pojazdy-w-polsce-od -kiedy.html [Access: November 2017] 
Comparative analysis of $V 2 \mathrm{~V}$ and $A 2 A$ technologies

Analiza porównawcza technologii V2V oraz A2A

[6] Article: 2013 The Year of the Autonomous Car. Available: https://www.pcmag.com/article2/0,2817,2428697,00.asp [Access: November 2017]

[7] Federal Motor Vehicle Safety Standards; V2V Communications. A Proposed Rule by the National Highway Traffic Safety Administration on 01/12/2017. Available: https://www.federalregister.gov/documents/2017/01/12/201631059/federal-motor-vehicle-safety-standards-v2v-communications [Access: September 2017]

[8] Harding, J., Powell, G., R., Yoon, R., Fikentscher, J., Doyle, C., Sade, D., Lukuc, M., Simons, J., \& Wang, J.: Vehicle-to-Vehicle Communications: Readiness of V2V Technology for Application. NHTSA. Washington 2014

[9] Ilková, V.; Ilka, A. (2017) "Legal Aspects of Autonomous Vehicles - an Overview". Proceedings of the 2017 21st International Conference on Process Control (PC), Štrbské Pleso, Slovakia, June 6 - 9, pp. 428-433.

[10] Convention on Road Traffic, drawn up in Vienna on 8 November 1968. Available: https://www.gddkia.gov.pl/userfiles/articles/i/infrastrukturarowerowa_3000/documents/konwencja_wiedenska.pdf [Access: November 2017]

[11] V2V Communication. Available: https://www.youtube.com/watch?v=3z09f CqmILU [Access: November 2017]

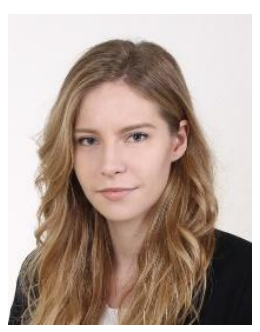

Agata Kotodziejska, M.Sc. Eng. - a graduate of the master's studies at the Faculty of Transport of Warsaw University of Technology with the specialisation of Intelligent Transport Systems. She obtained an engineer's degree at the same university, specialising in Transport Telematics.(Share 33\%)

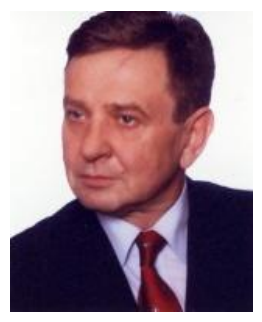

Prof. Miroslaw Siergiejczyk, PhD. Eng. - scientific fields of interest of the paper co-author concern among other issues of architecture and services provided by telecommunications networks and systems, especially from perspective of their applications in transport, reliability and operation of telecommunications networks and systems, modelling, designing and organising telecommunications systems for transport. (Share 33\%)

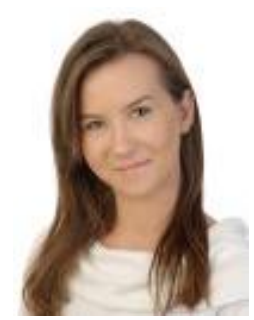

Karolina Krzykowska, M.Sc. Eng. - in research co-author of the article deals mainly with considerations on the reliability analysis of intelligent transport systems in the branch of road transport and aviation. She has several publications on this subject. (Share 33\%) 


\section{ANALIZA PORÓWNAWCZA TECHNOLOGII V2V ORAZ A2A}

\section{Wstęp}

Błędy popełniane przez użytkowników dróg, takich jak kierowcy, rowerzyści i piesi, są główną przyczyną większości wypadków. Potwierdziły to pogłębione badania przeprowadzone w Stanach Zjednoczonych i Wielkiej Brytanii w latach $1970 .{ }^{3} \mathrm{~W}$ celu poprawy bezpieczeństwa na drogach producenci samochodów na całym świecie pracują nad wprowadzaniem zaawansowanych systemów wspomagania kierowcy. Niektóre z tych systemów już funkcjonują oraz są dostępne na wyposażeniu pewnych modeli aut. Pozwalają one na uniknięcie niebezpiecznych sytuacji drogowych (kolizji i wypadków), na które człowiek nie ma wpływu, chociażby ze względu na ograniczone pole widzenia. Natomiast etap rozwoju motoryzacji, na którym czynnik ludzki zostanie całkowicie wyeliminowany, będzie to wprowadzenie do użytku pojazdów autonomicznych, nie wymagających obecności kierowcy. W dążeniu do osiągnięcia tego etapu producenci samochodowi napotykają jednak na szereg przeszkód, poczynając od ułomności maszyny oraz sposobu transmisji danych, a kończąc na aspektach prawnych. Niewątpliwie do niezawodnego działania tego typu technologii potrzebne są lata pracy i testów. Aby zobaczyć na jakim etapie prac stoją nowe technologie z zakresu inteligentnego transportu, zestawione zostaną ze sobą dwie z nich, a mianowicie V2V (Vehicle - to - Vehicle) oraz A2A (Autonomous vehicle - to - Autonomous vehicle).

\section{Analiza porównawcza}

\section{Funkcjonalność}

Vehicle-to-vehicle (V2V) jest technologią samochodową, która została zaprojektowana $\mathrm{w}$ ten sposób, aby stworzyć bezprzewodową sieć „ad hoc" na drogach. Dzięki temu technologia ta jest w stanie zapewnić wzajemną komunikację poszczególnych pojazdów. Specjalne wyposażenie tych pojazdów dostarcza im informacji o sytuacji na sieci dróg znajdującej się wokół nich. Zatem poszerza to znacznie pole manewru kierowcy, w porównaniu do jego dotychczasowej wiedzy o tym, co dzieje się jedynie bezpośrednio przed oraz za pojazdem.

Samochody objęte technologią V2V posiadają system ostrzegania kierowcy. Polega on na odbieraniu informacji od pozostałych pojazdów, a następnie na ostrzeżeniu kierowcy o zaistniałym niebezpieczeństwie poprzez alarmowanie wizualne lub/i dźwiękowe.

\footnotetext{
${ }^{3}$ Gaca S., Suchorzewski W., Tracz M.: Inżynieria ruchu drogowego. Teoria i praktyka. WKŁ, Wraszawa 2008, 2014
} 
Przykładem może być ostrzeżenie kierowcy o przeszkodach, czy też zatrzymanym pojeździe na pasie ruchu, aby mógł on bezpiecznie ominąć zagrażający bezpieczeństwu przedmiot. Ostrzeganie odbywa się poprzez wyświetlenie odpowiedniego symbolu na wyświetlaczu w samochodzie.

Aplikacje ostrzegające o bezpieczeństwie, będące częścią technologii V2V, to przede wszystkim:

- ostrzeganie przed kolizją (FCW),

- ostrzeżenie o hamowaniu awaryjnym (EEBL),

- asysta skrętu w lewo (LTA),

- ostrzeżenie przed zjechaniem z pasa ruchu (DNPW),

- ostrzeżenie o martwym punkcie / zmianie pasa ruchu (BS/LCW),

- asysta parkowania (PA),

- asysta wjazdu na skrzyżowanie (IMA).

Porozumiewanie się pojazdów znacznie ułatwia jazdę oraz zwiększa bezpieczeństwo na drogach. Nie jest jednak w stanie zastąpić kierowcy, ani podejmować za niego decyzji.

Autonomous vehicle - to - autonomous vehicle (A2A) natomiast jest technologią samochodową, polegającą na przekazywaniu informacji $\mathrm{z}$ danego pojazdu autonomicznego do pozostałych pojazdów autonomicznych. Pojazdy te docelowo mają być samojeżdżące oraz niewymagające obecności kierowcy. Dzięki porozumiewaniu się z pozostałymi pojazdami, ale także z infrastrukturą transportową, będą mogły bezkolizyjnie poruszać się po drogach. Zanim jednak to nastąpi, bezpieczniejszą formą będą pojazdy częściowo autonomiczne. $\mathrm{W}$ praktyce oznacza to, że pojazd jest $\mathrm{w}$ stanie samodzielnie się poruszać oraz podejmować decyzje na drodze za pomocą sztucznej inteligencji, jest całkowicie zautomatyzowany, natomiast wymaga obecności kierowcy oraz przejęcia przez niego kontroli w przypadku wykrycia nieprawidłowości w działaniu.

Działanie A2A polega na komunikacji pojazdów autonomicznych $\mathrm{w}$ celu zgromadzenia wszystkich danych niezbędnych do prawidłowego samoprowadzenia pojazdu. Priorytetem jest uniknięcie wszelkich kolizji na drodze, ale także odciążenie kierowcy poprzez zmechanizowanie każdego z etapów jazdy. Oprócz zwiększenia bezpieczeństwa, skutkuje to również zwiekszeniem komfortu podróżowania. $\mathrm{W}$ odróżnieniu od $\mathrm{V} 2 \mathrm{~V}$, technologia $\mathrm{A} 2 \mathrm{~A}$ jest $\mathrm{w}$ stanie zastąpić kierowcę oraz podejmować za niego decyzje na drodze.

\section{Sposób komunikacji}

Komunikacja V2V odbywa się na zasadzie wykorzystania bezprzewodowego protokołu podobnego do WiFi. Nazywa się on DSRC (Dedicated Short Range Communication). Mikrofalowa technologia DSRC jest to dedykowana komunikacja krótkiego zasięgu. W połączeniu $\mathrm{z}$ technologią GPS daje niskokosztowy system komunikacji $\mathrm{V} 2 \mathrm{~V}$, który zapewnia $360^{\circ}$ widok podobnie wyposażonych pojazdów w obrębie zasięgu komunikacji danego pojazdu. 
Agata Kołodziejska, Karolina Krzykowska, Mirostaw Siergiejczyk

Sieci bezprzewodowe na drogach są również określane jako sieci VANET. Te sieci wykorzystają część pasma 5,9 GHz, wydzieloną przez Kongres Stanów Zjednoczonych, nielicencjonowaną częstotliwość wykorzystywaną również przez WiFi. Norma US V2V, powszechnie znana jako WAVE („,Wireless Access for Vehicular Environments"- bezprzewodowy dostęp do środowisk transportowych), oparta jest na standardzie IEEE $802.11 \mathrm{p}$ niższego poziomu już w 2004 roku.

Wysyłane dane, wspólne dla wszystkich pojazdów, zawierają:

- aktualną pozycję GPS,

- kierunek jazdy i przyspieszenie pojazdu,

- informacje dot. sterowania pojazdem (stan skrzyni biegów, stan hamulca, kąt skrętu kierownicy),

- historię drogi pojazdu oraz przewidywanie drogi.

V2V nie obejmuje natomiast nawigacji, dostępu do Internetu, systemów wspomagania kierowcy, kamer cofania oraz innych zaawansowanych technologii.

Z kolei A2A wykorzystywać ma komunikację radiową niższej częstotliwości 5G. Bowiem niższa częstotliwość zapewnia pokrycie większego obszaru przez fale radiowe, zaś pokonywanie fizycznych przeszkód jest wtedy łatwiejsze. Dzięki wykorzystaniu technologii $5 \mathrm{G}$ pojazdy będą w stanie otrzymywać ogromne ilości danych, pochodzące $\mathrm{z}$ zewnętrznych serwerów. Nie byłoby wtedy konieczności lokalnego analizowania tych właśnie dnych. Według firmy Intel każdy autonomiczny pojazd codziennie generował bẹdzie średnio 4000 GB. Z tego względu niezbędne jest zapewnienie bezpiecznego oraz niezawodnego sposobu transmisji danych. Niemniej jednak na chwilę obecną nie ma możliwości zapewnienia tego typu łączności na skalę masową, zaś łączność 4G nie jest w tym przypadku wystarczająca. Natomiast w lutym 2017r. Intel zaproponował swoja autorską platformę łạczności 5G (pozwalającą na osiągnięcie szybkości transmisji sięgającej $7 \mathrm{Gbit} / \mathrm{s}$ ), przeznaczoną dla segmentu transportu autonomicznego. Dzięki tej platformie producenci samochodów, a także operatorzy telekomunikacyjni mogą prowadzić testy prototypów swoich rozwiązań.

\section{Wyposażenie pojazdów}

Nie jest znane dokładne wyposażenie pojazdów objętych technologią V2V lub $\mathrm{A} 2 \mathrm{~A}$, a spowodowane jest to głównie ciągłą pracą nad nimi, a także wciąż pojawiającymi się ulepszeniami i zmianami. Prawdopodobnie ilość zastosowanych urządzeń będzie różniła się w zależności od danej marki i modelu samochodu.

Podstawowe wyposażenie pojazdów $\mathrm{z}$ technologią $\mathbf{V 2 V}$ najprawdopodobniej będzie wymagało:

- czujników ultradźwiękowych,

- laserowych czujników odległości,

- czujników radarowych,

- kamer,

- procesora ogólnego przeznaczenia i związanej z nim pamięci,

- radiowego nadajnika oraz nadajnika-odbiornika,

- anten DSRC i GPS,

- odbiornika GPS. 
Comparative analysis of $V 2 \mathrm{~V}$ and $A 2 A$ technologies

Analiza porównawcza technologii V2V oraz A2A

Wyposażenie pojazdów autonomicznych z technologią A2A będzie obejmowało wszystkie urządzenia znajdujące się $\mathrm{w}$ pojeździe $\mathrm{z}$ technologią $\mathrm{V} 2 \mathrm{~V}$, z uwzględnieniem łączności 5G oraz nawigacji GPS. Jednak znaczącą różnicą w wyposażeniu jest tutaj obowiązkowa obecność czarnej skrzynki na pokładzie. Skrzynka ta będzie rejestrowała niezbędne parametry jazdy, a w przypadku częściowo autonomicznych pojazdów posłuży do określenia czy kierowca przejął sterowanie w danym momencie.

\section{Aspekty prawne}

Niemalże wszystkie państwa członkowskie Unii Europejskiej (z wyjątkiem Hiszpanii i Wielkiej Brytanii) podpisały i ratyfikowały Konwencję o Ruchu Drogowym, zwaną również Konwencją Wiedeńską. Jest to wielostronny międzynarodowy traktat Organizacji Narodów Zjednoczonych, dotyczący ogólnych przepisów ruchu drogowego. Do 23 marca 2016 r. wszelkie akty prawne przyjęte przez sygnatariuszy Konwencji musiały wymagać od kierowców, aby przez cały czas kontrolowali poruszający się pojazd.

Ze względu na informacyjną oraz ostrzegawczą rolę technologii $\mathbf{V 2 V}$ w ruchu drogowym, jest ona zgodna z postanowieniami Konwencji Wiedeńskiej. Nie istnieją również żadne istotne przeciwwskazania prawne dla powszechnego użytku tejże technologii. Natomiast jeżeli chodzi o odpowiedzialność prawną w przypadku wystąpienia kolizji lub wypadku, ponosi ją kierowca, gdyż system jest tylko jego narzędziem pomocniczym. To kierowca prowadzi pojazd oraz go kontroluje. Nie może polegać jedynie na jego ostrzeżeniach, zaś decyzje o manewrach na drodze podejmuje samodzielnie.

Z kolei w sprawie pojazdów objętych technologią A2A w 2016r. do artykułu 8 Konwencji Wiedeńskiej dodano nowy akapit pod nazwą "5bis". W efekcie pojazdy autonomiczne będą zgodne $\mathrm{z}$ Konwencją po wprowadzeniu tejże zmiany. Warunkiem jest jednak, że system autonomiczny będzie musiał posiadać możliwość przejęcia sterów przez kierowcę lub też będzie spełniał przyszłe wymagania przepisów ECE. Dalsze propozycje zmian w konwencji przedstawily Szwecja i Belgia. Czekają one wciąż na decyzję.

Niemcy w maju 2017r. przyjęły przepisy pozwalające samojeżdżącym pojazdom poruszanie się po drogach publicznych. Kraj takich koncernów jak BMW, Volkswagen i Daimler narzucił jednak pewne ograniczenia, które mają zagwarantować, że testy autonomicznych pojazdów będą bezpieczne.

Stany Zjednoczone zajęły się kwestią legalizacji autonomicznych samochodów już w czerwcu 2011 r. Ustawodawca Nevada uchwalił prawo zezwalające na korzystanie $\mathrm{z}$ autonomicznych samochodów. Nevada stała się $\mathrm{w}$ ten sposób pierwszą jurysdykcją na świecie, gdzie autonomiczne pojazdy mogą być legalnie eksploatowane na drogach publicznych.

Jeśli chodzi o federalne przepisy o ruchu drogowym, National Highway and Transportation Safety Administration (NHTSA) wydała zaktualizowane wytyczne dotyczące bezpiecznego rozwoju pojazdów autonomicznych we wrześniu 2016 r. 
Agata Kołodziejska, Karolina Krzykowska, Mirosław Siergiejczyk

Aktualizacja polityki składa się z czterech części: wytyczne dotyczące osiągów pojazdu, model polityki państwa, aktualne narzędzia regulacyjne NHTSA i ewentualne nowe działania regulacyjne, o których NHTSA uważa, że mogłyby być pomocne w zapewnieniu bezpiecznego wdrażania systemów AV (Autonomous Vehicle).

W przypadku wystąpienia kolizji lub wypadku z udziałem autonomicznego pojazdu sprawdzana jest czarna skrzynka, znajdująca się na jego pokładzie. Jeżeli $\mathrm{z}$ informacji $\mathrm{w}$ niej zapisanych wyniknie, że kierowca nie ingerował $\mathrm{w}$ przebieg jazdy, odpowiedzialność prawną poniesie producent pojazdu. Natomiast jeżeli okaże się, że kierowca przejął kontrolę nad pojazdem, odpowiedzialny będzie on. Należy wówczas pamiętać, że ręczne sterowanie pojazdem autonomicznym wiązać się będzie z ryzykiem.

\section{Przewidywany czas wejścia technologii na rynek}

Amerykańska Krajowa Administracja Bezpieczeńtwa Ruchu Drogowego (NHTSA) opublikowała w styczniu 2017r. proponowaną zasadę (,proposed rule”), wymagającą aby każdy nowy pojazd posiadał zdolności komunikacyjne Vehicleto-vehicle (V2V). Nie jest to jeszcze oficjalny wymóg, natomiast jeżeli wejdzie w życie w 2019r. (prawdopodobny termin dla reguł tego rodzaju):

- producenci byliby $\mathrm{W}$ stanie stopniowo wprowadzić tę technologię do swojej floty przez kilka następnych lat - po dwóch latach modelowania po przyjęciu ostatecznej zasady, okres wprowadzania rozpocząłby się w 2021r.,

- kolejno nastapiłby trzyletni okres wstępny/okres wprowadzania w celu przystosowania cyklu produkcyjnego producentów pojazdów, a wszystkie nowe pojazdy podlegające ostatecznej zasadzie porozumiewałyby się ze sobą już w 2023r.

W pierwszej kolejności NHTSA zastosowała analizę "breakeven" („wyjścia na czysto") w celu określenia roku kalendarzowego, w którym skumulowana wartość ekonomiczna korzyści związanych z bezpieczeństwem dzięki komunikacji V2V najpierw przekracza łączne koszty dla producentów pojazdów i nabywców, w celu zapewnienia możliwości V2V. Analiza wyrównania wykazała, że ten ważny próg zostanie osiągnięty pomiędzy 2029, a 2032 r., w zależności od skuteczności technologii aplikacji.

Następnie NHTSA przewidział wzrost przyszłych korzyści i kosztów proponowanej zasady w kolejnych latach modelowych po jego wejściu w życie. $\mathrm{W}$ tej analizie zidentyfikowano pierwszy rok modelowy, w którym korzyści dla bezpieczeństwa, wynikające $\mathrm{z}$ wymogu wyposażenia pojazdów w komunikację V2V przez cały okres ich użytkowania we flocie, przeważą nad wyższymi kosztami początkowymi ich wytwarzania. Pokazało to, że miałoby to miejsce w latach 2024-2026, jeśli proponowana zasada zaczęłaby obowiązywać w roku modelowym 2021. Stałoby się to szybciej niż rok „wyjścia na czysto"/"breakeven”, ponieważ skupienie się wyłącznie na kosztach i korzyściach $\mathrm{w}$ ciągu poszczególnych lat modelu unika się $\mathrm{w}$ tym obciążeniu kosztów instalacji komunikacji V2V na pojazdach produkowanych w poprzednich latach modelowych. 
Oczekuje się, że systemy V2V będą instalowane na coraz większej części floty pojazdów, jako że producenci dążą do spełnienia proponowanej zasady, która wymagałaby instalacji w $100 \%$ nowych pojazdów do roku 2023, co wynosić ma ponad 16 milionów sztuk rocznie. Ta duża produkcja zapewnia producentom możliwości obniżenia kosztów systemu poprzez proces uczenia się. W 2023 r. $100 \%$ pojazdów należałoby wyposażyć w radiatory DSRC.

Natomiast jeżeli chodzi o technologię A2A, wśród doniesień dziennika The Guardian znalazła się informacja, że do końca obecnej dekady na ulicach całego świata pojawi się już 200 milionów pojazdów aktywnie wymieniających informacje z siecią globalną (IoV/Internet pojazdów).

W Europie miasta w Belgii, Francji, Włoszech i Wielkiej Brytanii planują eksploatować systemy transportowe dla samochodów bez kierowcy, a Niemcy, Holandia i Hiszpania zezwoliły na testowanie samochodów samojezdnych w ruchu drogowym. Szwedzka firma produkująca samochody, Volvo, rozpoczęła testowanie 100 swoich autonomicznych samochodów na drogach publicznych prowadzonych w normalnym ruchu przez stałych klientów do 2017 roku. Firma ogłosiła współpracę ze szwedzkimi ustawodawcami i władzami transportowymi, aby przetestować samochody na 30-milowym odcinku drogi wokół Göteborga do 2017 r., naznaczając Volvo pierwszym publicznym pilotem w pełni autonomicznych pojazdów. Analitycy przewidują, że całkowicie autonomiczne samochody będą w sprzedaży do 2025-2030r.

W Europie samojeżdżące samochody najpierw muszą być przetestowane w europejskich warunkach, zaś oprogramowanie przystosowane do warunków trudniejszych niż kalifornijskie. Będą nad tym pracować działające w Europie koncerny (pierwsze testy na europejskich drogach ma za sobą już Nissan, zapowiadał je też Ford), lecz nie są one na razie tak zaawansowane w pracach nad technologią autonomicznej jazdy, jak np. Google czy Tesla - planują pokazać pierwsze auta $\mathrm{z}$ taką technologią w 2020/2021 roku.

Manager centrum badań i rozwoju firmy technologicznej Hitachi Europe Massimiliano Lenardi uważa, że takie samochody nie wejdą do sprzedaży przed 2025 rokiem. W Europie pierwszymi w pełni samojeżdżącymi pojazdami będą najprawdopodobniej ciężarówki jeżdżące po autostradach łączących duże miasta. One mogą pojawić się nawet przed rokiem 2025. Jego zdaniem wysoce zautomatyzowane pojazdy, ale nie w pełni autonomiczne, nadejdą jednak wcześniej, nawet w 2020 roku.

Freeing the Road: Shaping the future for autonomous vehicles (Uwolnić drogi: kształtowanie przyszłości pojazdów autonomicznych) to niezależny raport przygotowany przez think tank Policy Network na zlecenie Nissan Europe. Nowa, niezależna analiza ekonomiczna pokazuje, że pojazdy autonomiczne zaczną przynosić w nadchodzących dekadach dodatkowe $0,15 \%$ rocznego wzrostu gospodarczego w Europie. 
W rezultacie produkt krajowy brutto $w$ państwach Unii Europejskiej (UE-28) będzie, w ujęciu skumulowanym, o 5,3\% wyższy w 2050 roku niż obecnie i do tego czasu pojazdy autonomiczne przyniosą wzrost PKB łącznie o 17 bn EUR. ${ }^{4}$

Podczas międzynarodowej konferencji „Autonomiczna przyszłość transportu drogowego", zorganizowanej przez Instytut Transportu Samochodowego, zaprezentowano - po raz pierwszy nad Wisłą - pojazdy autonomiczne oraz określono wstępną datę ich dopuszczenia na polskich drogach. Pokonując istniejące bariery, w tym prawne związane np. z Konwencją wiedeńską o ruchu drogowym, czy krajowym Prawem o ruchu drogowym, można oczekiwać urynkowienia samochodów autonomicznych 4. generacji w 2025 roku, przy czym ich udział $\mathrm{w}$ skali globu nie przekroczy 1 procenta wszystkich pojazdów, ale już dekadę później osiągnie wartość kilkudziesięciu milionów sztuk.

\section{Przykłady pierwszych testów i wdrożeń}

Niedawno Volkswagen zapowiedział, że chce wprowadzać technologię komunikacji między pojazdami V2V od 2019 r., natomiast Toyota już ją oferuje w Japonii. Jako pierwszy na świecie producent, już prawie dwa lata temu, Toyota wprowadziła na tamtejszy rynek pakiet systemów bezpieczeństwa czynnego ITS Connect oparty na komunikacji między samochodami oraz między pojazdami a infrastrukturą drogową. Znalazł się już w wyposażeniu trzech, oferowanych na japońskim rynku modeli Toyoty (wśród nich Priusa i Crowna). ITS Connect ma być stopniowo wprowadzany do kolejnych modeli Toyoty, pomagając zredukować liczbę wypadków na skrzyżowaniach.

Mercedes zapowiedział w 2016r., że klasa E będzie jego pierwszym modelem seryjnym, wyposażonym $\mathrm{w}$ pełni zintegrowaną komunikację między samochodami. System Mercedesa jest już aktywny w połączeniu z systemem informacyjnym Comand Online $\mathrm{i}$ jest dostępny na 20 rynkach europejskich, Stanach Zjednoczonych i Chinach.

Natomiast Volvo rozpoczął komunikację samochodową z czołową linią modeli w Europie przed końcem roku 2016, dołączając do Mercedes-Benz i Toyota. Szwedzki producent samochodów na początku października 2016r. opublikował szczegółowe informacje na temat swojego rozwiązania opartego na chmurze podczas wprowadzenia nowego V90 Cross Country, które jest tylko jednym z modeli, które oferują tę technologię (wszystkie pojazdy z serii 90 - S90, V90 i XC90).

Odnośnie technologii pojazdów autonomicznych firma Google ujawniła pod koniec 2010 r., że zarejestrowała prawie 150000 mil testując swoją oryginalną, samobieżną Toyotę Prius. W sierpniu 2012r. zespół Waymo (spółka córka Alphabetu) ogłosił przejechanie ponad 300000 mil autonomicznych bez wypadków.

${ }^{4}$ Artykuł: Pojazdy autonomiczne mają przynieść europejskiej gospodarce 17 bilionów EUR do 2050 roku. [3] 
W grudniu 2013r. cztery stany (Nevada, Floryda, Kalifornia, Michigan) przyjęły przepisy prawa dotyczące autonomicznych pojazdów silnikowych. W czerwcu 2015r. zespół ujawnił, że przejechał ponad 1000000 mil pojazdami autonomicznymi. Testy prototypowych pojazdów odbywały się w Mountain View w Kalifornii. Waymo zamierza już jesienią 2017r. wypuścić na ulice samobieżne "taksówki" bez kierowcy (miasto Phoenix, Arizona). Autonomicznymi taksówkami będą minivany Chrysler Pacifica koncernu Chrysler, z którym Waymo nawiązało niedawno współpracę.

Pierwszym samochodem na rynku, który posiadał technologię częściowo autonomicznej jazdy był Mercedes-Benz Klasy S w 2012 roku. Mercedes-Benz wykorzystał okazję wydania przeprojektowanego flagowego modelu klasy $\mathrm{S}$, aby pokazać swoją autonomiczną technologię samochodową. Aby udowodnić, że jest gotowy na prawdziwy świat, Mercedes ujawnił, że S500 2014 przejechał z Mannheim do Pforzheim w Niemczech, w odległości ponad 60 mil, na drogach publicznych przez miasta i na autostradach.

Firma Nissan nie tylko wprowadziła w sierpniu 2013r. samobieżny model Leaf EV w Japonii, który będzie wykorzystywać do testowania autonomicznej technologii, ale także producent samochodów obiecał, że do 2020 r. wypuści na rynek wiele pojazdów typu self-driving. Już w marcu 2017r., jako jedyny producent samochodów, Nissan zdecydował się na prezentację jazdy w rzeczywistym ruchu miejskim w Londynie.

Ford testował swoje auta autonomiczne na amerykańskich drogach, teraz na europejskich drogach. Ford ma zamiar posiadać autonomiczny samochód zdatny do komercyjnego użytku do roku 2021. W 2017r. Ford zaczyna testować swoje autonomiczne pojazdy na autostradach w Europie.

\section{Podsumowanie}

W niniejszym artykule podjęty został problem rozwoju nowoczesnych technologii $\mathrm{w}$ zakresie inteligentnego transportu. Zaprezentowane zostały dwie koncepcje, a mianowicie V2V (Vehicle-to-Vehicle) oraz A2A (Autonomous vehicle-toAutonomous vehicle). Ich zestawienie $w$ tych samych kategoriach daje czytelnikowi niejaki pogląd na ich działanie oraz zaawansowanie we wdrażaniu.

$\mathrm{Z}$ wykonanej analizy jednoznacznie wynika, że każdy nowy pojazd będzie posiadał zdolności komunikacyjne Vehicle-to-Vehicle około 2021-2023r. Z kolei przewiduje się, że sprzedaż pojazdów całkowicie autonomicznych rozpocznie się na masową skalę w latach 2025-2030. Oznacza to, że technologia V2V wkroczy na rynek światowy nieco szybciej niż A2A. Wynika to $\mathrm{z}$ faktu, iż do porozumiewania się pojazdów autonomicznych niezbędne jest funkcjonowanie technologii 5G, co jeszcze nie nastąpiło. 
Dodatkowo technologia pojazdów autonomicznych jest znacznie bardziej skomplikowana niż technoloia V2V. O ile fizyczne wyposażenie obydwu rodzajów pojazdów jest do siebie zbliżone, o tyle rozwiązania software'owe będą się już bardziej od siebie różnić.

Potwierdzeniem zbliżającego się wprowadzenia do użytku codziennego omawianych technologii są liczne testy prowadzone przez marki samochodowe na całym świecie. Pierwsze prototypy pojazdów już istnieją, natomiast wymagają pewnych ulepszeń oraz testów w trudniejszych warunkach atmosferycznych przed ich całkowitym wprowadzeniem do sprzedaży.

\section{Literatura}

[1] Artykuł: All new cars could have V2V tech by 2023. Dostępny: https://techcrunch.com/2017/02/02/all-new-cars-could-have-v2v-tech-by2023/ [Dostęp: wrzesień 2017r.]

[2] Artykuł: Jak to działa: autonomiczne auta. Dostępny: https://www.chip.pl/ 2017/09/dziala-autonomiczne-auta/ [Dostęp: listopad 2017]

[3] Artykuł: Pojazdy autonomiczne mają przynieść europejskiej gospodarce 17 bilionów EUR do 2050 roku. Dostępny: https://newsroom.nissaneurope.com/pl/pl-pl/media/pressreleases/426164268/pojazdy-autonomicznemaja-przyniesc-europejskiej-gospodarce-17-bilionow-eur-do-2050-roku [Dostęp: listopad 2017]

[4] Artykuł: Samojeżdżące auta jeszcze długo nie pojawią się na ulicach Europy. Dostępny: https://businessinsider.com.pl/motoryzacja/autonomiczne-samochodykiedy-w-europie/jt2lxqq [Dostęp: listopad 2017]

[5] Artykuł: W pełni autonomiczne pojazdy w Polsce. Od kiedy? Dostępny: http://www.motofakty.pl/artykul/w-pelni-autonomiczne-pojazdy-w-polsce-odkiedy.html [Dostęp: listopad 2017]

[6] Artykuł: 2013 The Year of the Autonomous Car. Dostępny: https://www.pcmag.com/article2/0,2817,2428697,00.asp [Dostęp: listopad2017]

[7] Federal Motor Vehicle Safety Standards; V2V Communications. A Proposed Rule by the National Highway Traffic Safety Administration on 01/12/2017. Dostępny: https://www.federalregister.gov/documents/2017/01/12/201631059/federal-motor-vehicle-safety-standards-v2v-communications [Dostęp: wrzesień 2017r.]

[8] Harding, J., Powell, G., R., Yoon, R., Fikentscher, J., Doyle, C., Sade, D., Lukuc, M., Simons, J., \& Wang, J.: Vehicle-to-Vehicle Communications: Readiness of V2V Technology for Application. NHTSA. Washington 2014 
[9] Ilková, V. ; Ilka, A. (2017) "Legal Aspects of Autonomous Vehicles - an Overview". Proceedings of the 2017 21st International Conference on Process Control (PC), Štrbské Pleso, Slovakia, June 6 - 9, pp. 428-433.

[10] Konwencja o ruchu drogowym, sporządzona w Wiedniu dnia 8 listopada 1968r. Dostępna: https://www.gddkia.gov.pl/userfiles/articles/i/infrastrukturarowerowa_3000/documents/konwencja_wiedenska.pdf [Dostęp: listopad 2017]

[11] V2V Communication. Dostępny:https://www.youtube.com/watch?v=3z09fCqmILU [Dostęp: listopad 2017]

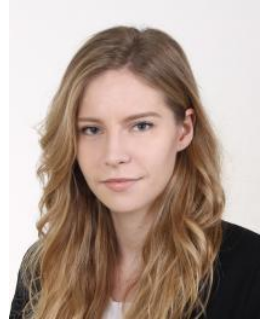

Mgr iṅ. Agata Kolodziejska - absolwentka studiów magisterskich na Wydziale Transportu Politechniki Warszawskiej o specjalności Inteligentne Systemy Transportowe. Tytut inżyniera uzyskata na tej samej uczelni, na specjalności Telematyka Transportu. (Udział 33\%)

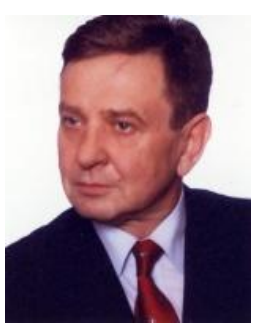

Prof. nadzw. dr hab. inz. Mirostaw Siergiejczyk -zainteresowania naukowe wspótautora referatu obejmuja między innymi problemy architektury $i$ ushug systemów $i$ sieci telekomunikacyjnych ze szczególnym uwzględnieniem możliwości ich wykorzystania $w$ transporcie, niezawodności $i$ eksploatacji systemów $i$ sieci teleinformatycznych, modelowanie, projektowanie $i$ organizacja sieci i systemów teleinformatycznych $w$ transporcie. (Udziat 33\%)

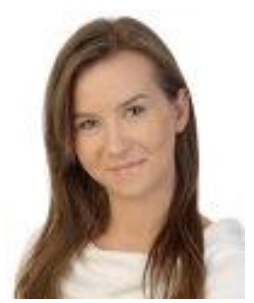

Mgr inz. Karolina Krzykowska - wspótautorka artykułu wbadaniach zajmuje się głównie analizami niezawodności inteligentnych systemów transportowych $w$ branży transportu drogowego i lotnictwa. Jest autorka kilku publikacji na ten temat. (Udziat 33\%) 